\section{DGGE Is More Sensitive for the Detection of Somatic Point Mutations than Direct Sequencing}

BioTechniques 27:266-268 (August 1999)

With the discovery of point mutations as a cause of disease, the need arises for methods to detect them with high sensitivity. Especially when the mutated allele is present in extremely low amounts, such as in DNA extracted from toxic thyroid nodules, which is often contaminated with surrounding tissue, blood and connective tissue, the sensitivity of the method to detect the mutation becomes increasingly important. Although numerous methods for mutation detection such as denaturing gradient gel electrophoreses (DGGE), temperature gradient gel electrophoreses (TGGE), single-strand conformation polymorphism (SSCP), constant denaturing gel electrophoreses (CD$\mathrm{GE}$ ), chemical mismatch cleavage (CMC) and direct sequencing exist, they differ in sensitivity, ease of application and cost effectiveness. Moreover, these basic techniques are subject to constant improvement [e.g., doublegradient (DG)-DGGE] (1), heteroduplex analysis (HA) (5) and improved fluorescent dye chemistry (8). It has already been shown that DGGE is more sensitive than SSCP for the detection of point mutations, and recent studies comparing the sensitivity of DGGE, SSCP and CMC found that DGGE and CMC were slightly more sensitive than $\operatorname{SSCP}(9,10)$. Our goal was to compare the sensitivity of DGGE to direct sequencing in the detection of mutated alleles among wild-type (WT) alleles, which to our knowledge, has not been carried out so far. First, the capability of DGGE in detecting the thyrotropin (TSH) receptor mutations Val656Phe, Asp633Glu, Thr632Ile, Ile486Phe, Asp619Gly, Ile630Leu, Ala623Val or the deletions 613-621 and 658-661 were determined. Secondly, the detection limit of DGGE and direct sequencing for identifying the mutant allele among WT alleles was compared utilizing the point mutations Val656Phe, Asp633Glu, Thr632Ile and Ile486Phe.
The mutant DNA was prepared by means of commercially available kits (QIAamp ${ }^{\circledR}$ Blood and Tissue Kit; Qiagen, Hilden, Germany) from toxic thyroid nodules or plasmids containing the mutated receptor and the WT DNA from healthy thyroid tissue surrounding the nodule or from plasmids with the WT TSH receptor sequence. The template consisted of a mixture of WT DNA containing decreasing concentrations of DNA from a toxic thyroid nodule or mutated plasmid DNA $(50 \%$, $25 \%, 12.5 \%, 6 \%, 3 \%, 1.5 \%$ or $0.8 \%$ ). Mutant plasmid DNA is not subject to the contamination with WT DNA mentioned above and can therefore be better quantitated, while the genomic DNA better reflects the situation in vivo, in which a 1:1 ratio of WT to mutant allele rarely exists. The mutation contents of the DNA derived from toxic thyroid nodules described in this article are referred to as putative because the exact mutation content cannot be determined due to unknown amounts of contamination with WT DNA. The DNA concentration in the template of either plasmids or genomic DNA was measured photometrically and then mixed in the appropriate ratios before the polymerase chain reaction (PCR) amplification. Two fragments of exon 10 of the TSH receptor containing different somatic mutations were analyzed by DGGE and direct sequencing in parallel. PCR amplification was performed in a Progene Thermal Cycler (Techne Ltd., Cambridge, England, UK) using 50 pmol of each appropriate primer, $200 \mu \mathrm{M}$ of each dNTP, $1.5 \mathrm{mM} \mathrm{MgCl}$, $1 \mathrm{U}$ of Taq DNA Polymerase (Invitek $\mathrm{GmbH}$, Berlin, Germany) and $10 \times$ reaction buffer containing $500 \mathrm{mM}$ Tris$\mathrm{HCl}, \mathrm{pH} 8.8,160 \mathrm{mM}\left(\mathrm{NH}_{4}\right)_{2} \mathrm{SO}_{4}$ and $0.1 \%$ Tween ${ }^{\circledR} 20$ and $100 \mathrm{ng}$ of DNA. To amplify fragment 1 (codon 586677 ) the following primers were used: forward 5'-GGCGGGGGCGGCGGGACGGGCGCGGGGGCGCGGCGGGCGTGACGCTCAACATAGTT-3' and reverse 5'-AGAGGAATGGATTGGCACAG-3' and for fragment 2 (codon 306-515): forward 5'-GGCGGGGGCGGCGGGACGGGCGCGGGGGCGCGGCGGGCGACCCGTGTGAAGACATAATGG-3' and reverse 5' -ATGACGGTCAGCGTATACACC- $3^{\prime}$. The forward primers had a 40-bp GC clamp attached to the $5^{\prime}$ terminus to prevent complete denaturing of the PCR product in the gradient gel. The melting

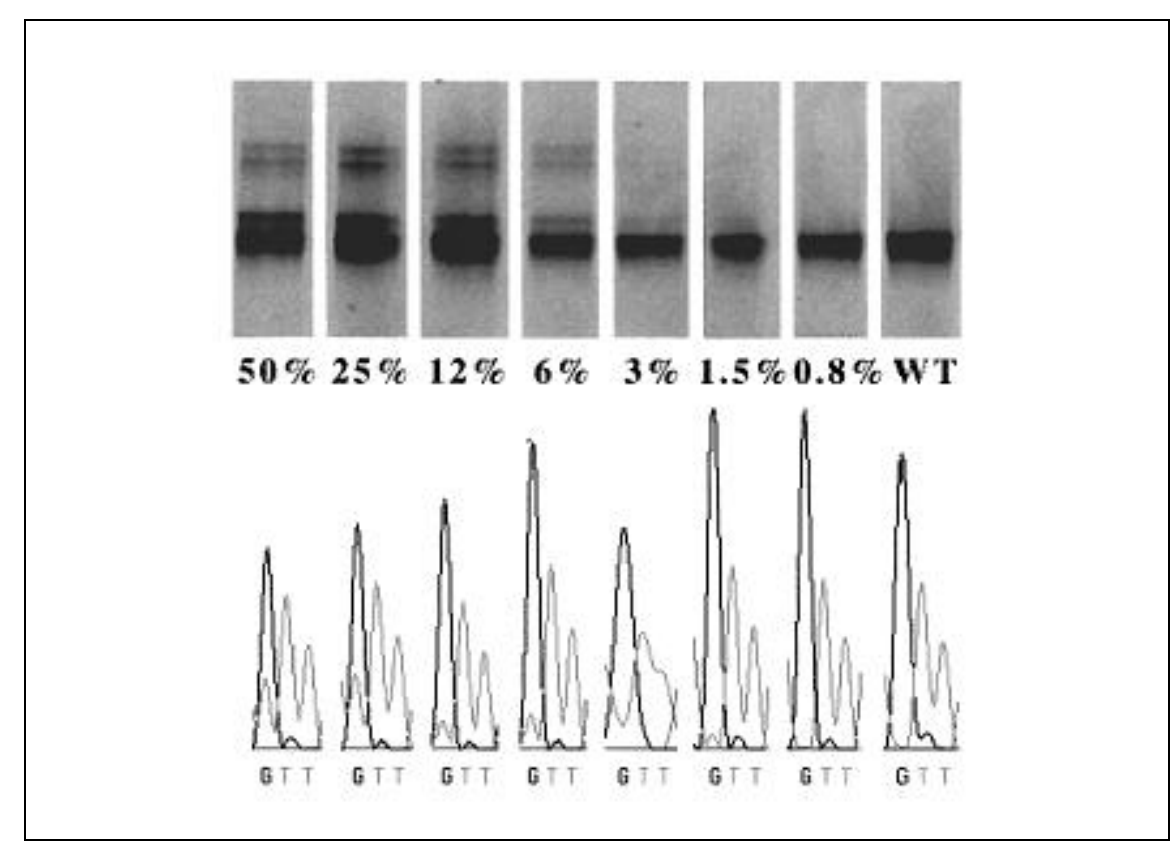

Figure 1. (Upper panel) DGGE analysis of a 310-bp segment of exon 10 of the TSH receptor containing the mutation in codon 656 (GTT to TTT) in different concentrations. The mutation can still be identified at $3 \%$ putative mutation content by DGGE. (Lower panel) Direct sequencing analysis of the same mutation. Twenty-five percent putative mutation content is required for detection by direct sequencing. The signal of the mutated base cannot be distinguished from normal background below $25 \%$ putative mutation content. 
Table 1. Comparison of DGGE and Direct Sequencing Analysis for the Detection of the TSH-Receptor Point Mutations Val656Phe, Asp633Glu, Thr632Ile and Ile486Phe

\begin{tabular}{|c|c|c|}
\hline \multirow[b]{2}{*}{ Mutation } & \multicolumn{2}{|c|}{$\begin{array}{l}\text { Minimum Amount of Mutated DNA } \\
\text { Necessary for Detection by: }\end{array}$} \\
\hline & DGGE & Sequencing \\
\hline $\begin{array}{l}\text { Val656Phe } \\
\text { (genomic) }\end{array}$ & $3 \%$ & $25 \%$ \\
\hline $\begin{array}{l}\text { Asp633Glu } \\
\text { (genomic) }\end{array}$ & $3 \%$ & $25 \%$ \\
\hline $\begin{array}{l}\text { Thr632lle } \\
\text { (genomic) }\end{array}$ & $6 \%$ & $50 \%$ \\
\hline $\begin{array}{l}\text { lle486Phe } \\
\text { (plasmid) }\end{array}$ & $3 \%$ & $12 \%$ \\
\hline \multicolumn{3}{|c|}{$\begin{array}{l}\text { Template DNA containing different amounts of mutated allele was PCR-ampli- } \\
\text { fied, and the resulting PCR fragments were both sequenced and analyzed by } \\
\text { DGGE. The template DNA consisted of a mixture of DNA isolated either from a } \\
\text { toxic thyroid nodule or surrounding healthy tissue containing decreasing con- } \\
\text { centrations of mutated DNA, except for the mutation lle486Phe, which was am- } \\
\text { plified from plasmid DNA. The percentages refer to the minimum amount of mu- } \\
\text { tant DNA in the PCR template required for detection by each method. }\end{array}$} \\
\hline
\end{tabular}

map characteristics of the PCR product were calculated with the Mac Melt ${ }^{\mathrm{TM}}$ program (Apple Computer, Cupertino, CA, USA). The PCR protocol consisted of initial denaturing at $95^{\circ} \mathrm{C}$ for 5 min, denaturing at $95^{\circ} \mathrm{C}$, annealing at $60^{\circ} \mathrm{C}$ and extension at $72^{\circ} \mathrm{C}$ for $30 \mathrm{~s}$ each for 35 cycles, with a final 10-min extension at $72^{\circ} \mathrm{C}$. After PCR amplification, an additional denaturing for 5 min and subsequent slow renaturation to $15^{\circ} \mathrm{C}$ at the rate of $1^{\circ} \mathrm{C} / \mathrm{min}$ was performed for the formation of heteroduplexes between WT and mutant PCR products. PCR product $(15 \mu \mathrm{L})$ was loaded on the denaturing gel and electrophoresed for $2 \mathrm{~h}$ (fragment 1 ) or $4 \mathrm{~h}$ (fragment 2) at $60^{\circ} \mathrm{C}$ and $160 \mathrm{~V}$ in $1 \times$ TAE buffer (40 mM Tris, $20 \mathrm{mM} \mathrm{Na-}$ acetate, $1 \mathrm{mM}$ EDTA, pH 7.8). DGGE was carried out in a Bio-Rad apparatus (Dcode $^{\mathrm{TM}}$ System for DGGE; Bio-Rad, Hercules, CA, USA) on a $6 \%$ polyacrylamide gel containing a linear gradient of $20 \%-60 \%$ (fragment 1 ) or $40 \%-60 \%$ (fragment 2) denaturant (100\% denaturant $=40 \%$ formamide, 7 M urea). Bands were detected by ethidium bromide staining under UV light. The remaining PCR product was polyethylene glycol (PEG)-precipitated for sequencing. The DNA was resuspended in $10 \mu \mathrm{L}$ of water, $2 \mu \mathrm{L}$ of which were mixed with $1 \mu \mathrm{L}$ primer and $2 \mu \mathrm{L}$ BigDye $^{\mathrm{TM}}$ Terminator Mixture (PE Biosystems, Foster City, CA, USA). BigDye terminator sequencing was chosen as the method for direct sequencing because the PCR primers can be utilized, and recent improvements in dye terminator design produce more even peak height comparable to dye primer sequencing. The sequencing reaction was performed in a Progene thermal cycler at $96^{\circ} \mathrm{C}$ for $30 \mathrm{~s}$ and $60^{\circ} \mathrm{C}$ for $4 \mathrm{~min}$ for 30 cycles. Analysis of the sequencing reaction was performed on a Model 310 Automatic Sequencer (PE Biosystems).

DGGE could detect the TSH receptor mutations Val656Phe, Asp633Glu, Thr632Ile, Ile486Phe, Asp619Gly, Ile630Leu, Ala623 Val and the deletions 613-621 and 658-661. The sensitivity of DGGE for detecting the mutant allele among WT alleles was superior to that of direct sequencing in the detection of all four mutations (Table 1). Figure 1 shows representative results for the mutation Val656Phe.

In a heterozygous condition, $50 \%$ of the alleles are affected. However, due to 
contamination of the affected tissue with surrounding healthy tissue, blood or connective tissue, the amount of mutated allele can be decreased. If this is the case, the level of mutated DNA could lie below the detection level of direct sequencing. The amount of contamination varies between the different DNA samples. This is illustrated by the mutation Thr632Ile, which required a putative mutation content of $6 \%$ for detection by DGGE and $50 \%$ for detection by direct sequencing (Table 1). In this case, higher amounts of contamination with WT DNA, compared to the other samples requiring only $3 \%$ mutation content, were most probably present. In contrast, by direct sequencing, the mutated plasmid DNA can be identified when present in only $12 \%$ of the sample as compared to $25 \%-50 \%$ for the patient genomic DNA. This difference could be due to the fact that plasmid DNA is not subject to the contamination with WT DNA as is the DNA extracted from a toxic thyroid nodule. The different degrees of contamination could also be one possible explanation for the discrepant results concerning the frequency of somatic TSH receptor mutations, which varies from $48 \%$ $82 \%$ in studies that investigated exons 9 and 10, in which all activating TSH receptor mutations described so far are located $(2-4,6,7,11)$. A better estimate for the real prevalence of somatic TSH receptor mutations in toxic thyroid nodules, and for other somatic mutations as well, should therefore be obtained by DGGE instead of direct sequencing studies. Based on these findings, we suggest the additional screening of mutation-negative samples analyzed by direct sequencing with DGGE or other more sensitive scanning methods. Those mutations detected only by DGGE could be further confirmed by excision of the mutated fragment out of the gel followed by sequencing. In addition, DGGE is the more efficient and cost-effective method in the screening of large sample numbers compared to direct sequencing. The reported data illustrate that DGGE is a method with an even higher sensitivity for identifying mutant alleles in a mixture of mutant and WT alleles compared to direct sequencing. Therefore, DGGE can detect point mu- tations that might be missed by direct sequencing when mutant levels are low, as in tumors.

\section{REFERENCES}

1.Cremonesi, L., S. Firpo, M. Ferrari, P.G. Righetti and C. Gelfi. 1997. Double-gradient DGGE for optimized detection of DNA point mutations. BioTechniques 22:326-330.

2.Führer, D., H.P. Holzapfel, P. Wonerow, W.A. Scherbaum and R. Paschke. 1997. Somatic mutations in the thyrotropin receptor gene and not in the $\mathrm{G}_{\mathrm{s}} \alpha$ protein gene in 31 toxic thyroid nodules. J. Clin. Endocrinol. Metab. 82:3885-3891.

3.Führer, D., C. Kubisch, U. Scheibler, P. Lamesch, K. Krohn and R. Paschke. 1998. The extracellular thyrotropin receptor domain is not a major candidate for mutations in toxic thyroid nodules. Thyroid 11:997-1001.

4.Holzapfel, H.-P., P. Wonerow, W. von Petrykowski, M. Henschen, W.A. Scherbaum and R. Paschke. 1997. Sporadic congenital hyperthyroidism due to a spontaneous germline mutation in the thyrotropin receptor gene. J. Clin. Endocrinol. Metab. 82:38793884.

5.Maynard, J.H. and M. Upadhyaya. 1998. High-throughput screening for the detection of unknown mutations: improved productivity using heteroduplex analysis. BioTechniques 25:648-651.

6.Parma, J., L. Duprez, J. Van Sande, J. Hermans, P. Rocmans, F. Van Vliet, S. Costagliola, P. Rodien, J. Dumont and G.J. Vassart. 1997. Diversity and prevalence of somatic mutations in the thyrotropin receptor and $\mathrm{G}_{\mathrm{s}} \alpha$ genes as a cause of toxic thyroid adenomas. J. Clin. Endocrinol. Metab. 82:2695-2701.

7.Paschke, R. and M. Ludgate. 1997. The thyrotropin receptor in thyroid diseases. N. Engl. J. Med. 337:1675-1681.

8.PE Biosystems. PRISM ${ }^{\mathrm{TM}}$ - Tips 4. Foster, City, CA.

9.Prosser, J. 1993. Detecting single-base mutations. Trends Biotechnol. 11:238-246.

10.Schwaab, R., J. Oldenburg, M.R. Lalloz, U. Schwaab, S.l. Pemberton, P. Hanfland, H.H. Brackmann, E.G. Tuddenham and K. Michaelides. 1997. Factor VIII gene mutations found by a comparative study of SSCP, DGGE, and GMC and their analysis on a molecular model of factor VIII protein. Hum. Genet. 101:323-332.

11.Tonacchera, M., L. Chiovato, A. Pinchera, P. Agretti, E. Fiore, F. Cetani, R. Rocchi, P. Viaccava, P. Miccoli and P. Vitti. 1998. Hyperfunctioning thyroid nodules in toxic multinodular goiter share activating thyrotropin receptor mutations with solitary toxic adenoma. J. Clin. Endocrinol. Metab. 83:492498.

We thank U. Scheibler (Surgical Department, Hospital of Dösen, Dösen, Germany) for provision of tissue samples. This work was supported by a grant from the Deutsche Forschungsgemeinschaft (DFG/PA423/10-
1) and IZKF Leipzig, BMB + F, Interdisciplinary Center for Clinical Research at the University of Leipzig, (01KS 9504, project B5-W). Address correspondence to Dr. Ralf Paschke, Department of Internal Medicine III, University of Leipzig, Ph.-Rosenthal Strasse 27, 04103 Leipzig, Germany. Internet:pasr@server3.medizin.uni-leipzig.de

Received 12 February 1999; accepted 3 May 1999.

\section{Barbara Trülzsch, Knut Krohn, Peter Wonerow and Ralf Paschke University of Leipzig Leipzig, Germany}

\section{High-Resolution, Fluorescence-Based Differential Display on a DNA Sequencer Followed by Band Excision}

BioTechniques 27:268-271 (August 1999)

Differential display polymerase chain reaction (DD-PCR) of mRNA has become a procedure for quantitative detection of differentially expressed genes in distinct cell populations $(5,6,9,10)$. The standard procedure includes selective reverse transcription of polyadenylated RNA using specific anchored oligo(dT) primers, PCR amplification of cDNA using the oligo(dT) primer and an arbitrary upstream primer, resolution of PCR products on denaturing sequencing gels and radioactive detection methods. To avoid hazardous radioisotopes, several nonradioactive methods for identification of differential display cDNAs have been reported, including ethidium bromide visualization in agarose gels (12), silver staining $(3,7)$ and chemiluminescent detection $(1,13)$ of cDNA bands.

Several protocols have been published reporting the use of automated 